\section{Job Satisfaction among Dental Assistants in Brazil}

Nelson Rubens Mendes Loretto ${ }^{1}$, Arnaldo de França Caldas Jr² , Luiz Gutenberg Toledo de Miranda Coelho Junior ${ }^{2}$

The aim of the present study was to investigate the expressed levels of job satisfaction of dental assistants working in Brazil and whether there are relationships among professional formation standards, workplace relations and job satisfaction. An analytical cross-sectional study was carried out with a calculated sample of 443 dental assistants. A questionnaire was developed for this purpose and its validity was verified in a pilot study. The questionnaire provided data for socioeconomic and demographic categorization and identified the variables that could be correlated to professional satisfaction. Job satisfaction was stratified into satisfaction and no satisfaction. All participants signed an informed consent form. Data were analyzed using SPSS software, version 13.0. Pearson's chi-square and Fisher's exact tests were performed. Among the 443 participants, 94.6\% were women, $72.7 \%$ were aged between 21 and 40 years and $65.0 \%$ were single. Over half had 37 or more months of job experience and had completed their course at a public institution. The majority earned between US $\$ 141.00$ and US\$190.00 per month. Job satisfaction was mentioned by $81.5 \%$ of the dental personnel. It was found that most subjects were satisfied with their job, and that the level satisfaction is influenced negatively by salary,workplace, workload and dentist's personality.

\author{
'Department of Operative Dentistry; \\ ${ }^{2}$ Department of Dental Public \\ Health, UPE - University of \\ Pernambuco, Camaragibe, PE, Brazil
}

Correspondence: Prof. Dr. Arnaldo de França Caldas Junior, Estrada de Aldeia, Km 13, Prive Portal de Aldeia, Aldeia, 54783-010 Camaragibe, PE, Brasil. Tel: +55-81-9971-3652. e-mail: arnaldocaldas@pq.cnpq. br / caldasjr@alldeia.com.br

\section{Introduction}

According to the International Labor Organization (1), satisfaction may be associated with motivation or attitude, or may be a result of the psychosocial working environment. Factors such as the working environment, workers' skills and needs, organizational conditions, culture and personal influence health, performance and satisfaction at work.

Currently, workers' satisfaction has an important place in modern management understanding and the organization's success is directly proportional to job satisfaction of the employee in all organizations (2).

The rapid change in all activity sectors, particularly in healthcare service and policies, had brought job dissatisfactions among the healthcare workers. There are also the negative working conditions, which hinder effective and efficient service of health workers. In summary, the work burden has increased, incomes have become insufficient, relationships and working environment have been corrupted, and working hazards, despite being accepted as part of the profession, also has increased (3).

Work should be a permanent source of pleasure and fulfillment. One does not work simply for survival, but for one's complete realization. Work can often cause suffering, and some indicators of this suffering are fear (physical and moral), boredom, overload, misunderstanding of organizational decisions, conflict between individual and organizational values, uncertainties about the future of the organization. The workers themselves are losing the meaning of the work, doubts about their social and professional value, feelings of injustice, lack of confidence, feelings of inactivity, among others (4).

Career progression, working practices and job satisfaction of dental healthcare professionals has received increasing attention in the literature. The need for this stems from two sources: the recognition of the important role of professionals complementary to dentistry and the necessity to consider the influence of changing work patterns upon human resource planning (5).

To healthcare professionals job satisfaction has been discussed in relation to issues such as high turnover of dental staff, potential loss of productivity resulting from turnover and quitting the dental field entirely. In addition, job satisfaction can vary according to patient needs, requiring different types and intensities of physical and emotional efforts to those who assist them (6).

Satisfaction is a major factor for remaining at a job (7) and job satisfaction is capable of determining a change of employment and even the professional activity, thus dental personnel often interrupt their career for reasons both within and out of the profession (8).

Although the salary does not represent the only motivational factor - other factors, such as working schedule, job conditions and inter-professional relationship are also considered -, it is often related to major dissatisfaction at the job (4).

For Gercsak (9), the three major reasons why hygienists disliked their jobs were boring and routine work with dentists that would not allow them to do all the procedures 
that they are up to do, the benefits were not provided by their employers, and some patients were uncooperative, showing poor oral hygiene with no desire to improve.

A critical factor is to understand the working patterns of dental hygienists, as hygienist numbers expand in the future, in order to undertake a thorough evidence-based workforce planning (10).

Three issues arise from a review of the reported job satisfaction of dental assistants. First, although the literature on job satisfaction is extensive, there is little research on job satisfaction among health service workers in Brazil, especially among dentists, dental assistants and dental hygienists. Second, different studies used different methods, making comparisons difficult (Table 1). Third, there are no studies that compared the relationship among professional formation, working relations and job satisfaction across Latin American countries. For these reasons, the aim of the present study was to investigate the expressed levels of job satisfaction of dental assistants working in Brazil and the relationship among professional formation standards, working relations and job satisfaction.

\section{Material and Methods} the cities of Recife and Caruaru in the state of Pernambuco, northeastern region of Brazil. Using the formula for finite populations, a minimum sample of 339 dental workers was established. In order to compensate for potential losses, 68 subjects (20\%) were added, resulting in an assumed sample

Table 1. Different approaches to job satisfaction: key words, population and results

\begin{tabular}{|c|c|c|c|}
\hline Authors & Key words & Population & Results \\
\hline Hopcraft et al. (10) & $\begin{array}{l}\text { Dental hygienist; } \\
\text { Employment; } \\
\text { Career satisfaction; } \\
\text { Workforce }\end{array}$ & $\begin{array}{c}\text { Dental } \\
\text { hygienists }\end{array}$ & $\begin{array}{c}97 \% \text { of } \\
\text { satisfaction } \\
\text { with their job }\end{array}$ \\
\hline Puriene et al. (11) & $\begin{array}{c}\text { Mental health; } \\
\text { Job satisfaction; } \\
\text { Occupational hazards; } \\
\text { Burn-out; Nervousness; } \\
\text { Depression }\end{array}$ & Dentists & $\begin{array}{c}80.7 \% \text { of } \\
\text { satisfaction } \\
\text { with their job }\end{array}$ \\
\hline Luzzi et al. (6) & $\begin{array}{l}\text { Job satisfaction; } \\
\text { Dentist; } \\
\text { Public sector; } \\
\text { Recruitment; } \\
\text { Retention }\end{array}$ & $\begin{array}{l}\text { Registered } \\
\text { clinical } \\
\text { dentists }\end{array}$ & $\begin{array}{c}81 \% \text { were } \\
\text { satisfied with } \\
\text { their job }\end{array}$ \\
\hline Gibbons et al. (12) & $\begin{array}{l}\text { Job satisfaction; } \\
\text { Career break; } \\
\text { United Kingdom. }\end{array}$ & $\begin{array}{l}\text { Dental } \\
\text { hygienists }\end{array}$ & $\begin{array}{c}52 \% \text { were } \\
\text { very satisfied } \\
\text { with their job }\end{array}$ \\
\hline Locker et al. (13) & $\begin{array}{l}\text { Work stress; } \\
\text { Job satisfaction; } \\
\text { Well-being }\end{array}$ & $\begin{array}{c}\text { Dental } \\
\text { assistants }\end{array}$ & $\begin{array}{l}\text { Only } 36.1 \% \text { of } \\
\text { subjects were } \\
\text { fully satisfied } \\
\text { with their job }\end{array}$ \\
\hline
\end{tabular}

of 407 professionals. However, 443 dental assistants took part in this study. All the participants received and signed an informed consent form, in accordance with Resolution 196/96 of the Brazilian Ministry of Health. This research was approved by the institutional Ethics Committee (Process \#25/2006).

A self-reported questionnaire with 49 open and closed questions was elaborated based on previous studies $(5,11)$. Its validity was verified in a pilot study, which determined socioeconomic and demographic categorization and identified the variables that could be correlated to professional satisfaction. All interviews were conducted by an experienced researcher and were held at the working places of all subjects.

The validity of the questionnaire was tested in a pilot study that found no need to modify any issue, since all dental assistants understood the meaning of each question. To assess the test-retest reliability of the survey, 30 dental assistants who participated in the study were randomly selected and interviewed a second time. This second interview was conducted at least one month after the first one and presented the dental assistant the same questions used in the first interview. The analysis of the obtained data showed a high consistency in the dental assistants' responses, with Kappa values of 1 for the category variables and the intraclass correlation coefficient ranged from 0.97 to 1.00 for numerical variables. Most of the questions had multiple alternatives, but only one should be chosen.

Job satisfaction was determined by a single question and it wasstratified in satisfaction and no satisfaction. Additional information was collected on the following variables: a) sociodemographics: age of respondent, gender, marital status, number of children and schooling level; b) related to work: training course, place of formation, job experience, salary and place of employment.

Frequency distribution was used to assess the general sample characteristics and to investigate possible raw data entry errors. Measures of central tendency and of dispersion were calculated in addition to the proportions. Paired data analysis was performed in order to verify if there was or not a relation between the independent variables. Pearson's chi-square and Fisher's exact tests were conducted to study the associations between pairs of variables. The significance level was set at 5.0\%, with a confidence interval of 95\%.

\section{Results}

Out of the 443 subjects who filled the questionnaire, $94.6 \%$ were women, mean age $32.01 \pm 9.076$ years; $65.0 \%$ were single, $49.0 \%$ 
had children and out of these $38.2 \%$ had only one child. With respect to schooling, 76.7\% had completed secondary education (Table 2). Among the 426 who responded about job experience, the majority (55.3\%) had 37 or more months on the job (Table 3).

A total of $63.2 \%$ dental assistants had professional formation (half of these studied at public institutions) and worked in private offices (48.3\%) (Table 3 ).

Job satisfaction demonstrated a statistically strong significant association with salary $(p<0.001)$ and place of employment $(p=0.002)$. Job satisfaction was cited by $81.55 \%$ of the dental assistants (Table 3 ). Among the not satisfied, low salary (63.2\%) was the most frequent reason.

Table 2. Sociodemographic variables of the sample

\begin{tabular}{|c|c|c|}
\hline Sociodemographic variables & $\mathrm{n}$ & $\%$ \\
\hline \multicolumn{3}{|l|}{ Gender $(n=443)$} \\
\hline Male & 24 & 5.4 \\
\hline Female & 419 & 94.6 \\
\hline \multicolumn{3}{|l|}{ Age (mean $32.01 \pm 9.076)(n=437)$} \\
\hline Up to 20 years old & 34 & 7.7 \\
\hline 21 to 40 years old & 322 & 72.7 \\
\hline Over 40 years old & 81 & 18.3 \\
\hline Not informed & 6 & 1.4 \\
\hline \multicolumn{3}{|l|}{ Marital Status $(n=443)$} \\
\hline Single & 288 & 65.0 \\
\hline Married & 155 & 35.0 \\
\hline \multicolumn{3}{|l|}{ Children $(n=443)$} \\
\hline Yes & 217 & 49.0 \\
\hline No & 211 & 47.6 \\
\hline Not informed & 15 & 3.4 \\
\hline \multicolumn{3}{|l|}{ Number of children $(n=217)$} \\
\hline 1 & 83 & 38.2 \\
\hline 2 & 81 & 37.3 \\
\hline 3 & 18 & 8.3 \\
\hline$\geq 4$ & 8 & 3.7 \\
\hline Not informed & 27 & 12.5 \\
\hline \multicolumn{3}{|l|}{ Level of education $(\mathrm{n}=443)$} \\
\hline Complete primary education & 33 & 7.4 \\
\hline Incomplete secondary education & 60 & 13.7 \\
\hline Complete secondary education & 326 & 76.7 \\
\hline Undergraduate & 12 & 2.6 \\
\hline Graduate & 12 & 2.6 \\
\hline
\end{tabular}

Satisfaction was negatively influenced by salary and was most cited by those who earn between US $\$ 141.00$ and US $\$ 190.00$ per month (42.6\%). The workplace is another factor that influenced satisfaction, especially among those who work in private offices (52.9\%) (Table 4). Among those who held more than one job, the percentages of no satisfaction were low (private dental office + public service $=2.9 \%$ and public service + private job $=1.5 \%$ ). Hour workload also influenced no satisfaction, with $40 \mathrm{~h} /$ week (41.2\%) and $44 \mathrm{~h} /$ week $(32.3 \%)$. The standing position required for the work also influenced no satisfaction $(80.9 \%)$. The last factor with a negative influence on job

Table 3. Professional formation, place of formation, job experience, place of employment and job satisfaction of the subjects

\begin{tabular}{|c|c|c|}
\hline Sociodemographic variables & $\mathrm{n}$ & $\%$ \\
\hline \multicolumn{3}{|l|}{ Professional formation $(n=443)$} \\
\hline Yes & 280 & 63.2 \\
\hline No & 150 & 33.9 \\
\hline Not informed & 13 & 2.9 \\
\hline \multicolumn{3}{|c|}{ Place of professional formation $(n=280)$} \\
\hline Public Institution & 140 & 50.0 \\
\hline Private Institution & 134 & 47.9 \\
\hline Not informed & 6 & 2.1 \\
\hline \multicolumn{3}{|l|}{ Job experience $(n=443)$} \\
\hline Up to 12 months & 86 & 19.41 \\
\hline 13 to 36 months & 95 & 21.45 \\
\hline 37 months and over & 245 & 55.30 \\
\hline Not informed & 17 & 3.84 \\
\hline \multicolumn{3}{|l|}{ Place of employment $(n=443)$} \\
\hline Private office & 214 & 48.3 \\
\hline Public service & 173 & 39.1 \\
\hline Private company & 34 & 7.7 \\
\hline Others & 4 & 0.9 \\
\hline Private office + Public service & 6 & 1.4 \\
\hline Public service + Private company & 1 & 0.2 \\
\hline Public service + Others & 1 & 0.2 \\
\hline Not informed & 10 & 2.3 \\
\hline \multicolumn{3}{|l|}{ Job satisfaction } \\
\hline Yes & 361 & 81.5 \\
\hline No & 68 & 15.3 \\
\hline Not informed & 14 & 3.2 \\
\hline Total & 443 & 100 \\
\hline
\end{tabular}


satisfaction was the dentist's predominant personality trait. The main assessment was that of a pleasant individual for $72.2 \%$ of the dental personnel. Even so, $58.1 \%$ of the nonsatisfied workers cited the dentist's personality as a negative influence on satisfaction. The traits mentioned as being negative - ill-humor, rudeness and aloofness - influenced satisfaction with $14.5 \%, 1.6 \%$ and $1.6 \%$, respectively.

\section{Discussion}

Over the past 15 years, the Federal Dental Council (FDC) in Brazil granted registration as dental assistants for all who worked in private or public clinics for at least 2 years. Training course was not required neither a proof of their skills. Nowadays, to be a dental assistant in Brazil, a 1 -year training course is required and for a dental hygienist is required a 2-year training course. After finishing the course, register at the FDC is also required.

The dental assistants in Brazil cannot do any work directly in the mouth of the patient. Tasks like take dental radiographs, removal sutures, apply topical anesthetics to gingival tissues or cavity-preventive agents to teeth, remove excess cement used in the filling process, and place rubber dams is not allowed in Brazil. However, these activities are

Table 4. Relationship among job satisfaction, salary and place of employment

\begin{tabular}{|c|c|c|c|c|c|c|c|}
\hline \multirow{3}{*}{ Variable } & \multicolumn{4}{|c|}{ Job satisfaction } & \multirow{2}{*}{\multicolumn{2}{|c|}{ Total }} & \multirow{3}{*}{$\mathrm{p}$ value } \\
\hline & \multicolumn{2}{|c|}{ Yes } & \multicolumn{2}{|c|}{ No } & & & \\
\hline & $\mathrm{n}$ & $\%$ & $\mathrm{n}$ & $\%$ & $\mathrm{~N}$ & $\%$ & \\
\hline \multicolumn{8}{|l|}{ Salary* } \\
\hline$\leq$ US $\$ 140,00$ & 57 & 15.8 & 20 & 29.4 & 77 & 17.9 & \multirow{5}{*}{$\mathrm{p}<0.001^{* *}$} \\
\hline US $\$ 141,00$ to US $\$ 190,00$ & 132 & 36.6 & 29 & 42.6 & 161 & 37.5 & \\
\hline$>$ US\$190,00 & 121 & 33.5 & 11 & 16.2 & 132 & 30.7 & \\
\hline Not informed & 51 & 14.1 & 8 & 11.8 & 59 & 13.9 & \\
\hline Total & 361 & 84.1 & 68 & 15.9 & 429 & 100 & \\
\hline \multicolumn{8}{|l|}{ Place of employment } \\
\hline Private office & 173 & 47.9 & 36 & 52.9 & 209 & 48.8 & \multirow{9}{*}{$\mathrm{p}=0.002^{* *}$} \\
\hline Public service & 146 & 40.4 & 25 & 36.8 & 171 & 39.9 & \\
\hline Private company & 30 & 8.3 & 4 & 5.9 & 34 & 7.9 & \\
\hline Others & 4 & 1.1 & - & - & 4 & 0.9 & \\
\hline Private office + Public service & 4 & 1.1 & 2 & 2.9 & 6 & 1.4 & \\
\hline Public service + Private cmpany & 1 & 0.3 & - & - & 1 & 0.2 & \\
\hline Public service + Others & - & - & 1 & 1.5 & 1 & 0.2 & \\
\hline Not informed & 3 & 0.9 & - & - & 3 & 0.7 & \\
\hline total & 361 & 84.1 & 68 & 15.9 & 429 & 100 & \\
\hline
\end{tabular}

*Minimum monthly wage in Brazil $=$ US $\$ 190,00 .{ }^{* *}$ Pearson test. ${ }^{* * *}$ Fisher`s exact test. all allowed for dental hygienists.

Primary education is required of all Dental Assistants, while the Dental Hygienists must have a secondary level. Predominance of secondary level education in the studied sample is a sign of progress. It is known that low schooling has two immediate effects: lower salaries and no registration at the Federal Dental Council (FDC). Proper schooling predisposes the individual to develop practical intelligence, a measure of the capacity to articulate and mobilize knowledge, skills, attitudes and values, which prepare the individual to face both predictable and unusual situations.

It is important to emphasize that this study was conducted with dental assistants only. The dental hygienists were not involved in the research. However, the final sample is representative of the registered population of dental assistants in the state of Pernambuco.

The substantial presence of women in this professional category is directly proportional to their increase in the general population, to more years of schooling among women, to their emancipation in the labor force, to the affective traits in the care-giving process and to the Kingsley's confirmation of sensitivity, as in 1844 he recommended that women take part in the oral care (13). The mean age of 32.01 years $(s d=9.076$ ) confirms what psychology teaches about the psychosocial maturity of women as compared with men, despite the fact that the latter have more opportunities and are better remunerated. Women finish their basic education before men and are ready to enter the working force or university before their male counterparts.

Marital status (single), when correlated with age, proved to be almost double that of married individuals in the 20-40 years of age group. When age increased (over 41 years), the number of married subjects was expected to increase, a fact that did not occur. Square chitest indicated a positive association between age and marital status.

Reduced family size, with the majority having one child, indicates financial concerns and with the implications of a large number of offspring, especially considering the salary of dental workers and 
the opportunities for education, health, leisure, housing, transportation and quality of life in Brazil. The mean time of service of 2.37 years, varying from 1 month to 30 years, may have influence on the development of working experience, but at the same time it may lead to a lackadaisical job performance.

Professional qualification, obtained by completing the formation course, has a strong consequence on salaries, but also reveals an important aspect: the hiring of unqualified individuals, competing for low salaries, not registered in the FDC and possibly providing low-quality service. The cross-plotting of formation data against salary data showed that those who earn less are not professionally qualified $(p<0.001)$. There is also an influence on job opportunity. The question arises: why do dentists hire unqualified personnel? Are there few formation courses offered? Do public oral health policies not take into account that qualified dental personnel could significantly reduce oral health problems? Despite these considerations, it is important to highlight that many dentists are still unaware of the attributes and competence of dental personnel at their different levels, and in private offices this personnel is trained predominantly for administrative services.

The association between salary and workplace was also significant, since a majority (54.9\%) of those who earned more than US\$190.00 per month worked in the public service. The fact that $47.4 \%$ work $40 \mathrm{~h}$ per week, points to an important consideration. Given that the majority of dental personnel are women and work in the so-called "double shift" (professional and domestic activities), it was expected that this would influence satisfaction. But it did not, leaving open the possibility of a qualitative study to investigate the reasons.

Job satisfaction is an attitude of an employee over a period of his/her job, so the factors of job satisfaction and dissatisfaction change over time (14). When people feel their salaries are not fair, or the work conditions are poor, or the benefits insufficient, they feel dissatisfied with the organization and their job. However, even if these conditions are perfect, the elimination of dissatisfaction does not mean that employees feel fulfilled, only that they are no longer dissatisfied. It is employee fulfillment, not satisfaction, that predicts performance. It is the individual manager who creates, or fails to create, fulfillment (4). Salary in our research was the main factor of no satisfaction and was lower among the younger workers, with a strong association between these two variables $(p<0.001)$.

Job satisfaction was positive for the absolute majority of dental personnel, a finding which differs from studies in the literature involving dentistry or other professions. Age, for example, did not influence satisfaction, although previous studies have found younger dental assistants being less satisfied with their career $(6,15)$. The same occurred with time of service, marital status, number of children, professional formation and schooling variables. Salary had a negative influence on satisfaction. It is an important predictor of job satisfaction. However, other related factors like promotions, acknowledged work effort and the importance/challenge of the job are also taken into account (14). Salary may cause the worker to quit or even to abandon the profession (4); on the other hand it can be a motivational factor for attracting and keeping skilled professionals (16). Other factors that had influence were hour workload and the dentist's predominant personality trait.

Dental work is a unique social interaction influenced by specific demands of the clinical practice, exposure to an intimate and very sensitive area of the human body, personal characteristics and emotions of a health care provider and its recipient (11). Educational programs should be directed to help professionals to cope with their professional duties without hazardous effects on their physical and mental health.

There was a high level of job satisfaction, despite the fact that among the non satisfied, salary, workplace, hour workload and the standing position at work, in addition to the dentist's personality, have a negative influence on satisfaction.

\section{Resumo}

0 objetivo deste trabalho foi investigar os niveis de satisfação no trabalho dos auxiliares de saúde bucal e a existência de associação entre estes níveis e o local de trabalho e o salário. Um estudo transversal foi realizado com uma amostra de 443 profissionais definida por cálculo amostral. Um questionário para avaliar satisfação no trabalho foi desenvolvido e validado através de um estudo piloto. 0 questionário também permitiu a categorização das variáveis socioeconômicas e demográficas, identificando aquelas relacionadas à satisfação no trabalho. A satisfação no trabalho foi categorizada em satisfação e não satisfação. Todos os participantes assinaram um termo de consentimento livre e esclarecido. Os dados foram analisados através do software SPSS 13.0 e para determinar associação entre variáveis foram utilizados os testes qui-quadrado de Pearson e exato Fisher. Dos 443 participantes, a maioria era do sexo feminino $(94,6 \%)$, solteira $(65,0 \%)$, com média de idade de $32,01 \pm 9,076$ anos. Mais da metade tinham 37 ou mais meses de experiência de trabalho e completado o curso em uma instituição pública. A maioria ganhava entre US\$141,00 e 190,00 por mês. A satisfação no trabalho foi citada por $81,55 \%$ dos profissionais. A maioria do grupo estudado estava satisfeita com seu trabalho, e essa satisfação foi influenciada negativamente pelo salário, local de trabalho, carga horária e personalidade do dentista.

\section{References}

1. International Labour Office (1984). Psychosocial factors at work: recognition and control. Report of the Joint ILO/WHO Committee on Occupational Health - Ninth Session. Geneva: International Labour Office.

2. Erdem R, Rahman S, Avci L, Göktas B, Senoglu B, Firat G. Investigating job satisfaction and burnout levels of the persons working for the Hospitals at City Center of Elazig, Turkey. J Appl Sci Res 2008;4:188201. 
3. Ersoy $F$, Edirne $T$, Yýldýrým RC. Vocational satisfaction of health personnel. IV National of Health and Hospital Management Symposium Book; 2001 September 27-28; Ankara, 2001:382-387.

4. Leimbach M. Redefining employee satisfaction: business performance, employee fulfillment, and leadership practices. Wilson Learning Worldwide Inc. 2006. Available from: http://www.wilsonlearning.com.

5. Gibbons DE, Corrigan $M$, Newton JT. A national survey of dental hygienists: working patterns and job satisfaction. Br Dent J 2001;190:207-210.

6. Luzzi L, Spencer AJ, Jones K, Teusner D. Job satisfaction of registered dental practitioners. Aust Dent J 2005;50:179-185.

7. Butters JM, Willis DO. Satisfaction level of dental office personnel. Gen Dent 1993;41:236-240.

8. Gibbons $D E$, Corrigan $M$, Newton JT. The working practices and job satisfaction of dental therapists: findings of a national survey. Br Dent J 2000;189:435-438.

9. Gercsak JR. A study of job satisfaction and turnover of dental auxiliaries in British Columbia. A thesis submitted in partial fulfillment of the requirements for the degree master of business administration in the Department of Economics and Commerce. Simon Fraser University, April 1976.
10. Hopcraft M, McNally C, Ng C, Pek L, Pham TA, Phoon WL, et al.. Working practices and job satisfaction of Victorian dental hygienists. Aust Dent J 2008;53:61-66.

11. Puriene A, Aleksejuniene J, Petrauskiene J, Balciuniene I, Janulyte V. Self-perceived mental health and job satisfaction among Lithuanian dentists. Ind Health 2008;46:247-252.

12. Locker D. Work stress, job satisfaction and emotional well-being among Canadian dental assistants. Community Dent Oral Epidemiol 1996;24:133-137.

13. Peterson S. El odontólogo y su assistente. Buenos Aires: Mundi 1977;24-26.

14. Kamal $Y$, Hanif F. Pay and job satisfaction: a comparative analysis of different Pakistani commercial banks. MPRA, 2009: 1-21. Available from: http://mpra.ub.uni-muenchen.de/16059.

15. Kruger E, Smith K, Tennant M. Dental therapy in Western Australia: profile and perceptions of the workforce. Aust Dent J 2006;51:6-10.

16. Vaillant D. Atraer y retener buenos profesionales en la profesión docente: políticas en Latinoamérica. Rev Educ 2006;340:117-140.

Received February 9, 2012 Accepted August 14, 2012 